\title{
ANALISIS PENGGUNAAN SARANA DAN PRASARANA \\ UNTUK MENUNJANG KEGIATAN BELAJAR MAHASISWA DI UNIVERSITAS PGRI PALEMBANG TAHUN AKADEMIK 2016/2017
}

\author{
${ }^{1}$ Neta Dian Lestari \& ${ }^{2}$ Boby Agus Yusmiono \\ ${ }^{1,2}$ Universitas PGRI Palembang \\ email: 1neta_obyta@yahoo.com ${ }^{2}$ boby.yusmiono@yahoo.com
}

\begin{abstract}
The benefits of educational facilities greatly affect the smoothness and sustainability of the learning process. Universitas PGRI Palembang has good facilities and infrastructure ranging from comfortable lecture room and has been completed by infocus, accredited library $A$ and integrated lab, and other facilities that support the student learning process, but sometimes facilities that have been maximally completed by University is not in good use by students or by lecturers. This research aimed at investigating the value of benefit from the use of facilities and infrastructure to support the student learning activities in academic year 2016/2017. This research was descriptive by using quantitative approach. The result concluded that the infrastructure facilities in Universitas PGRI Palembang in good categories which were seen from the number of student statement 80,20.
\end{abstract}

Keywords: Facilities and Infrastructure; Supporting Learning Activities; Universitas PGRI Palembang.

\section{PENDAHULUAN}

Perguruan Tinggi sebagai bentuk organisasi diartikan sebagai wadah dari kumpulan orang-orang terdidik yang saling bekerja sama untuk mencapai tujuan tertentu yakni tujuan pendidikan. Keberhasilan program pendidikan dalam proses belajar mengajar sangat dipengaruhi oleh beberapa faktor yaitu peserta didik, kurikulum, tenaga kependidikan, dana, prasarana dan sarana, dan faktor lingkungan lainnya. Apabila faktor tersebut terpenuhi dengan baik dan bermutu maka akan menghasilkan peningkatkan mutu pendidikan di Indonesia. Pendapat Aprilana dkk (2017) juga menyebutkan bahwa manajer pendidikan harus menguasai pengetahuan tentang metode, proses, prosedur serta teknik melakukan kegiatan khusus dan kemampuan untuk memanfaatkan dan mendayagunakan sarana prasarana untuk mendukung kegiatan.

Salah satu faktor yang mendukung keberhasilan program pendidikan dalam proses pembelajaran yaitu sarana dan prasarana. Sarana dan prasarana pendidikan adalah salah satu sumber daya yang menjadi tolak ukur mutu Perguruan Tinggi dan perlu peningkatan terus menerus seiring dengan perkembangan ilmu pengetahuan dan teknologi yang cukup canggih serta mampu bersaing di ekonomi era digital MEA. Dalam penyelengaraan pendidikan, sarana prasaran sangat di butuhkan untuk menghasilkan kualitas lulusan yang terbaik.

Undang-undang Republik Indonesia nomor 12 tahun 2012 Tentang pendidikan tinggi adalah jenjang pendidikan setelah 
pendidikan menengah yang mencakup program diploma, program sarjana, program magister, program doktor, dan program profesi, serta program spesialis, yang diselenggarakan oleh perguruan tinggi berdasarkan kebudayaan bangsa Indonesia. Paragraf 5 Sumber Belajar, Sarana, dan Prasarana Pasal 41 (1) Sumber belajar pada lingkungan pendidikan tinggi wajib disediakan, difasilitasi, atau dimiliki oleh Perguruan Tinggi sesuai dengan Program Studi yang dikembangkan. (2) Sumber belajar sebagaimana dimaksud pada ayat (1) dapat digunakan secara bersama oleh beberapa Perguruan Tinggi. (3) Perguruan Tinggi menyediakan sarana dan prasarana untuk memenuhi keperluan pendidikan sesuai dengan bakat, minat, potensi, dan kecerdasan Mahasiswa.

Masalah yang dihadapi, kegiatan belajar tidak akan berjalan dengan baik apabila sarana dan prasarana kurang memadai. Akibatnya hasil belajar yang diperoleh akan rendah. Manfaat sarana prasarana pendidikan sangat mempengaruhi kelancaran serta keberlangsungan proses pembelajaran. Universitas PGRI Palembang, telah memiliki sarana dan prasarana yang baik mulai dari ruang kuliah yang nyaman dan telah di lengkapi oleh infokus, perpustakaan yang terakreditasi A dan lab terpadu, serta fasilitas lain yang menunjang proses belajar mahasiswa, namun terkadang fasilitas yng telah maksimal di lengkapi oleh Universitas tidak di manfaatkan dengan baik oleh mahasiswa maupun oleh dosen. Tujuan Penelitian yang ingin dicapai adalah untuk mengetahui Nilai Manfaat dari Penggunaan Sarana dan Prasarana Untuk Menunjang Kegiatan Belajar Mahasiswa di Universits PGRI Palembang Palembang Tahun Akademik 2016/2017. Oleh karena itu untuk melihat nilai manfaat dari penggunaan sarana dan prasarana, peneliti melakukan penelitian dengan judul "Analisis Penggunaan Sarana dan Prasarana untuk Menunjang Kegiatan Belajar Mahasiswa di Universitas PGRI Palembang Tahun Akademik 2016/2017”.

Pengertian sarana dan prasarana pendidikan adalah semua keperluan yang diperlukan dalam proses belajar-mengajar, baik yang bergerak maupun yang tidak bergerak agar pencapaian tujuan pendidikan dapat berjalan dengan lancar, teratur, efektif dan efisien. Menurut Rohman dan Amri (2012:267) "sarana pendidikan adalah peralatan dan perlengkapan yang secara langsung dipergunakan dan menunjang proses pendidikan, khususnya proses belajar mengajar". Sarana adalah semua fasilitas yang diperlukan dalam proses belajar mengajar, baik yang bergerak maupun yang tidak bergerak agar pencapaian tujuan pendidikan dan berjalan dengan lancar, teratur, efektif dan efesien (Kristiawan dkk 2017). 
Menurut Daryanto (2008:51) "sarana pendidikan adalah segala sesuatu yang mendukung secara langsung terhadap kelancaran proses pembelajaran. Sedangkan menurut Kamus Besar Bahasa Indonesia "Sarana pendidikan adalah segala sesuatu yang dapat dipakai sebagai alat dalam mencapai maksud atau tujuan".

Berdasarkan uraian di atas dapat disimpulkan bahwa sarana prasarana pendidikan adalah semua fasilitas atau perlengkapan dasar yang secara langsung dan tidak langsung dipergunakan untuk menunjang proses pendidikan dan demi tercapainya tujuan khususnya proses belajar mengajar seperti, gedung, ruang, meja kursi, alat-alat, media pengajaran, ruang perpustakaan, ruang laboraturium dan sebagainya.

Jenis sarana prasarana pendidikan Menurut Matin dan Fuad (2016 : 29) dapat digolongkan ke dalam buku, alat, perabot, bangunan, dan tanah. (1) Pengadaan Buku, salah satu tujuan negara adalah mencerdaskan kehidupan bangsa. Salah satu sarana untuk mencapai tujuan itu ialah tersedianya bahan bacaan yaitu buku, majalah, atau rekaman bahan pustaka lain. (2) Pengadaan Alat, alat yang dimaksud dalam hal ini terdiri atas alat-alat kantor dan alat-alat pendidikan. Adapun yang termasuk alat kantor ialah alat-alat yang biasa digunakan di kantor seperti: mesin tulis, mesin hitung, mesin stensil, komputer, alatalat pembersih dan sebagainya. Sedangkan yang termasuk dalam alat pendidikan ialah alat-alat yang secara fungsional dalam proses belajar mengajar seperti alat peraga, alat praktik, alat laboraturium, alat kesenian, alat olahraga dan sebagainya. (3) Pengadaan Perabot, perabot ialah barang-barang yang berfungsi sebagai tempat untuk menulis, istirahat, tempat penyimpanan alat atau bahan. Contoh: meja, kursi, lemari, rak, filling kabinet dan sebagainya.

Keberhasilan program pendidikan melalui proses belajar mengajar sangat dipengaruhi oleh banyak faktor, salah satu di antaranya adalah tersedianya sarana dan prasarana pendidikan yang memadai disertai pemanfaatan dan pengelolaan secara optimal. Standar sarana prasarana pendidikan ini mencangkup (UU No. 12 Tahun 2012): (1) Kriteria minimum sarana yang terdiri dari perabot, peralatan pendidikan, media pendidikan, buku dan sumber belajar lainnya, teknologi informasi dan komunikasi, serta perlengkapan lain yang wajib dimiliki oleh setiap Perguruan Tinggi. (2) Kriteria minimum prasarana yang terdiri dari lahan, bangunan, ruang-ruang dan instalasi daya dan jasa yang wajib dimiliki oleh setiap Perguruan Tinggi.

Penerimaan Mahasiswa Baru Perguruan Tinggi menjaga keseimbangan antara jumlah maksimum Mahasiswa dalam 
setiap Program Studi dan kapasitas sarana dan prasarana, Dosen dan tenaga kependidikan, serta layanan dan sumber daya pendidikan lainnya. Perguruan Tinggi menyediakan sarana dan prasarana serta dana untuk mendukung kegiatan organisasi kemahasiswaan. (Undang-undang Republik Indonesia Nomor 12 Tahun 2012 Tentang $\begin{array}{llll}\text { Pendidikan } & \text { Tinggi bagian }\end{array}$ Kemahasiswaan Paragraf 1)

Yang dimaksud dengan "prinsip akuntabilitas" adalah kemampuan dan komitmen untuk mempertanggungjawabkan semua kegiatan yang dijalankan Perguruan Tinggi kepada semua pemangku kepentingan sesuai dengan ketentuan peraturan perundang-undangan. Akuntabilitas antara lain dapat diukur dari rasio antara Mahasiswa dan Dosen, kecukupan sarana dan prasarana, penyelenggaraan pendidikan yang bermutu, dan kompetensi lulusan. (Undang-undang Republik Indonesia Nomor 12 Tahun 2012 Tentang Pendidikan Tinggi Pasal 63 Huruf a)

Standar yaitu, "Standar satuan biaya operasional" adalah biaya penyelenggaraan Pendidikan Tinggi di luar investasi dan pengembangan. Biaya investasi antara lain biaya pengadaan sarana dan prasarana serta sumber belajar. (Undang-undang Republik Indonesia Nomor 12 Tahun 2012 Tentang Pendidikan Tinggi Pasal 88 Ayat (1))

Paragraf 5 Sumber Belajar, Sarana, dan Prasarana Pasal 41 “(1) Sumber belajar pada lingkungan pendidikan tinggi wajib disediakan, difasilitasi, atau dimiliki oleh Perguruan Tinggi sesuai dengan Program Studi yang dikembangkan. (2) Sumber belajar sebagaimana dimaksud pada ayat (1) dapat digunakan secara bersama oleh beberapa Perguruan Tinggi. (3) Perguruan Tinggi menyediakan sarana dan prasarana untuk memenuhi keperluan pendidikan sesuai dengan bakat, minat, potensi, dan kecerdasan Mahasiswa".

Peraturan Menteri Riset, Teknologi, dan Pendidikan Tinggi Republik Indonesia Nomor 44 Tahun 2015 tentang Standar Nasional Pendidikan Tinggi BAB II Bagian Kesatu Ruang Lingkup Standar Nasional Pendidikan Pasal 4 adalah sebagai berikut.

(1) Standar Nasional Pendidikan terdiri atas: (a)standar kompetensi lulusan; (b) standar isi pembelajaran; (c) standar proses pembelajaran; (d) standar penilaian pembelajaran; (e) standar dosen dan tenaga kependidikan; (f) standar sarana dan prasarana pembelajaran; (g) standar pengelolaan pembelajaran; dan (h) standar pembiayaan pembelajaran.

(2) Standar Nasional Pendidikan sebagaimana dimaksud pada ayat (1) menjadi acuan dalam menyusun, menyelenggarakan, dan mengevaluasi kurikulum.

Bagian Kedua Standar Kompetensi Lulusan Pasal 5

(1) Standar kompetensi lulusan merupakan kriteria minimal tentang kualifikasi kemampuan lulusan yang mencakup sikap, pengetahuan, dan keterampilan yang dinyatakan dalam rumusan capaian pembelajaran lulusan. 
(2) Standar kompetensi lulusan yang dinyatakan dalam rumusan capaian pembelajaran lulusan sebagaimana dimaksud pada ayat (1). Digunakan sebagai acuan utama pengembangan standar isi pembelajaran, standar proses pembelajaran, standar penilaian pembelajaran, standar dosen dan tenaga kependidikan, standar sarana dan prasarana pembelajaran, standar pengelolaan pembelajaran, dan standar pembiayaan pembelajaran.

(3) Rumusan capaian pembelajaran lulusan sebagaimana dimaksud pada ayat (1) wajib: (a) mengacu pada deskripsi capaian pembelajaran lulusan KKNI; (b) memiliki kesetaraan dengan jenjang kualifikasi pada KKNI.

\section{METODE PENELITIAN}

Definisi operasional variabel dalam penelitian ini adalah: Sarana prasarana dalam pembelajaran yang ada di kelas yang digunakan oleh Dosen dan mahasiswa yaitu, media power point, Kalkulator, alat peraga, alat praktik, komputer, alat laboraturium dan materi tentang Akademik yang menunjang. Sarana prasarana dalam pembelajaran yang dimiliki mahasiswa maupun dosen yaitu buku paket, buku catatan, Bahan Ajar dan alat tulis.

Metode penelitian pada dasarnya merupakan cara ilmiah untuk mendapatkan data dengan tujuan dan kegunaan tertentu. Metode yang digunakan dalam penelitian ini adalah metode diskriptif menggunakan pendekatan kuantitatif. Metode penelitian diskriptif adalah penelitian yang dimaksudkan untuk menyelidiki keadaan, kondisi atau hal lain-lain yang sudah disebutkan, yang hasilnya dipaparkan dalam bentuk laporan penelitian (Arikunto, 2014:03). Sedangkan metode penelitian kuantitatif dapat diartikan sebagai metode penelitian yang berlandaskan pada filsafat positivisme, digunakan untuk meneliti pada populasi atau sampel tertentu (Sugiyono, 2014:14)

\section{Menurut Sugiyono}

(2014:117)

"Populasi adalah wilayah generalisasi yang terdiri atas: objek/subjek yang mempunyai kualitas dan karakteristik tertentu yang ditetapkan oleh peneliti untuk dipelajari dan kemudian ditarik kesimpulannya". Maka peneliti hanya mengambil FKIP sebagai Populasi yaitu sebanyak 11 Program studi dan yang tercantum pada tabel berikut ini:

Tabel 1. Populasi Penelitian (Pangkalan Data Pendidikan Tinggi copyright@2013-2017)

\begin{tabular}{|c|c|c|}
\hline No & $\begin{array}{c}\text { Program Studi } \\
\text { Pendidikan }\end{array}$ & $\begin{array}{c}\text { Jumlah } \\
\text { Mahasiswa }\end{array}$ \\
\hline 1 & Bahasa indonesia & 431 \\
\hline 2 & Bahasa Inggris & 405 \\
\hline 3 & Matematika & 432 \\
\hline 4 & Fisika & 159 \\
\hline 5 & Sejarah & 107 \\
\hline 6 & Akuntansi & 333 \\
\hline 7 & Geografi & 338 \\
\hline 8 & Olah raga & 1.486 \\
\hline 9 & Sendratasik & 611 \\
\hline 10 & PG PAUD & 261 \\
\hline 11 & PGSD & 19 \\
\hline & Jumlah & 4582 \\
\hline
\end{tabular}

Sampel adalah sebagian atau wakil populasi yang diteliti (Arikunto, 2014:174). Sedangkan menurut Sugiyono (2014:118) "Sampel adalah bagian dari jumlah dan karakteristik yang dimiliki oleh populasi 
tersebut. Berdasarkan kedua pengertian di atas dapat disimpulkan bahwa sampel adalah bagian dari populasi yang akan diteliti. Berdasarkan tabel populasi di atas peneliti hanya mengambil jurusan IPS. Maka yang menjadi sampel dalam penelitian ini adalah Mahasiswa Program Studi Pendidikan Sejarah, Pendidikan Akuntansi dan Pendidikan Geografi sebanyak 150 Mahasiswa (Sampel Bertujuan).

Tabel 2. Sampel Penelitian

\begin{tabular}{clc}
\hline No & $\begin{array}{c}\text { Program Studi } \\
\text { Pendidikan }\end{array}$ & $\begin{array}{c}\text { Jumlah } \\
\text { Mahasiswa }\end{array}$ \\
\hline 1. & Sejarah & 50 \\
2. & Akuntansi & 50 \\
3. Geografi & 50 \\
Jumlah & $\mathbf{1 5 0}$ \\
\hline
\end{tabular}

Dokumentasi adalah mencari data mengenai hal-hal atau variabel yang berupa catatan, transkrip, buku, surat kabar, majalah, prasasti, notulen rapat, legger, agenda, nilai raport dan sebagainya (Arikunto, 2014: 274). Dokumen ini digunakan mengumpulkan data hasil belajar siswa dengan cara mengutip data dari hasil nilai raport yang ada di Perguruan Tinggi sesuai dengan nama-nama mahasiswa yang diteliti.

Angket merupakan teknik pengumpulan data yang dilakukan dengan cara memberi seperangkat pertanyaan atau pernyataan tertulis kepada responden untuk dijawabnya (Sugiyono, 2014:199). Metode angket digunakan untuk mengetahui data tentang sarana prasarana pendidikan yang mendukung proses pembelajaran baik yang terdapat di ruang kelas maupun yang dimiliki Dosen dan mahasiswa.

Tabel 3. Alternatif Jawaban Angket (Sugiyono, 2014: 200)

\begin{tabular}{ccc}
\hline No & Alternatif & Skor \\
\hline 1. & "Sangat baik" & 4 \\
2. & "Baik" & 3 \\
3. & "Sedang" & 2 \\
4. & "Buruk" & 1 \\
\hline
\end{tabular}

Peneliti menggunakan metode angket untuk mengelola dan menganalisa data-data yang telah diperoleh, dan untuk mendapatkan suatu hasil kesimpulan dari penelitian yang telah dilakukan. Teknik analisa data pada penelitian ini menggunakan persentase skor jawaban angket, untuk menghitung besarnya persentase skor jawaban angket dapat dicari dengan rumus:

$$
\mathbf{P}=\frac{\boldsymbol{f}}{\boldsymbol{n}} \mathbf{x} \mathbf{1 0 0 \%} \quad \text { (Sudijono, 2010:43) }
$$

Keterangan:

$\mathrm{P}=$ angka persentase

$\mathrm{F}=$ frekuensi yang sedang dicari persentasenya

$\mathrm{N}=$ jumlah frekuensi atau banyaknya individu

Tabel 4. Kategori Persentase Angket (Purwanto, 2013:103)

\begin{tabular}{ccc}
\hline No & Interval & Kategori \\
\hline 1. & $81-100$ & Baik sekali \\
2. & $76-85$ & Baik \\
3. & $60-75$ & Cukup \\
4. & $55-59$ & Kurang \\
5. & $\leq 54$ & Sangat kurang \\
\hline
\end{tabular}

\section{HASIL PENELITIAN DAN PEMBAHASAN}

Pada tahun 2000 STKIP PGRI Palembang dikembangkan menjadi Universitas PGRI Palembang, hal ini tertuang dalam Surat Keputusan Dirjen Dikti 
Depdiknas Republik Indonesia Nomor : 97/D/O/2000, tanggal 9 Juni 2000. Fakultas

Keguruan dan Ilmu Pendidikan (FKIP) memiliki 6 (Enam) jurusan dan 11 (Sebelas) Program Studi, yaitu Jurusan Pendidikan Bahasa dan Seni terdiri dari Program Studi Pendidikan Bahasa Inggris dan Program Studi Pendidikan Bahasa dan Sastra Indonesia, Jurusan MIPA terdiri Program Studi Pendidikan Matematika dan Program Studi Pendidikan Fisika. Jurusan IPS terdiri dari Program Studi Pendidikan Sejarah dan Program Studi Pendidikan Akutansi. Jurusan Ilmu Pendidikan terdiri dari Program Studi Bimbingan dan Konseling. Jurusan Pendidikan Olahraga terdiri dari Program Studi Pendidikan Olahraga. Jurusan Sandratasik, Jurusan Pendidikan Guru terdiri dari Program Studi PGPAUD dan Program studi PGSD.

Sarana dan Prasarana yang menunjang proses belajar mengajar yang dimiliki oleh Univ. PGRI Palembang yaitu; (1) Perputakaan yang terakreditasi A, (2) Lab terpadu tempat laboratorium terpadu yang menunjang proses belajar mengajar jurusan IPS yaitu: Lab. Akuntansi, Lab. Sejarah, dan Lab. Geografi, (3) Wifi sebagai sarana internet mahasiswa selain buku-buku yang ada di ruang perpustakaan, (4) Infokus yang terdapat di ruang kelas, (5) Alat tulis yang terdapat di dalam kelas, (6) Bahan ajar yang disediakan oleh dosen pengampu dan lain sebagainya.

Penelitian ini dilakukan di Universitas PGRI Palembang berlokasi di Jalan Jend A Yani Lrg.Gotong Royong 9/10 Ulu Palembang. Sampel dalam penelitian ini berjumlah 150 Mahasiswa Jurusan IPS di Universitas PGRI Palembang tahun Akademik 2017/2018.

Penelitian dilakukan dengan cara membagikan angket sarana prasarana pendidikan kepada responden. Setelah dibagikan responden mengisi jawaban yang cocok menurut responden.

Angket penelitian terdiri dari 10 indikator dengan 30 pernyataan, pilihan aternatif jawaban angket, antara lain:

1. Jika jawaban "Sangat baik" diberikan skor 4

2. Jika jawaban "Baik" diberikan skor 3

3. Jika jawaban "Cukup" diberikan skor 2

4. Jika jawaban "Tidak Baik" diberikan skor 1

Untuk menganalisis data yang diteliti mengenai sarana dan prasarana pendidikan Untuk menunjang kegiatan belajar mahasiswa FKIP Jurusan IPS peneliti menyusun angket sebanyak 30 item pernyataan dari 35 angket karena ada 5 angket yang tidak valid, jadi hanya 30 item yang di gunakan. 
Tabel 5. Pernyataan Mahasiswa Tentang Sarana dan Prasarana Di Universitas PGRI Palembang

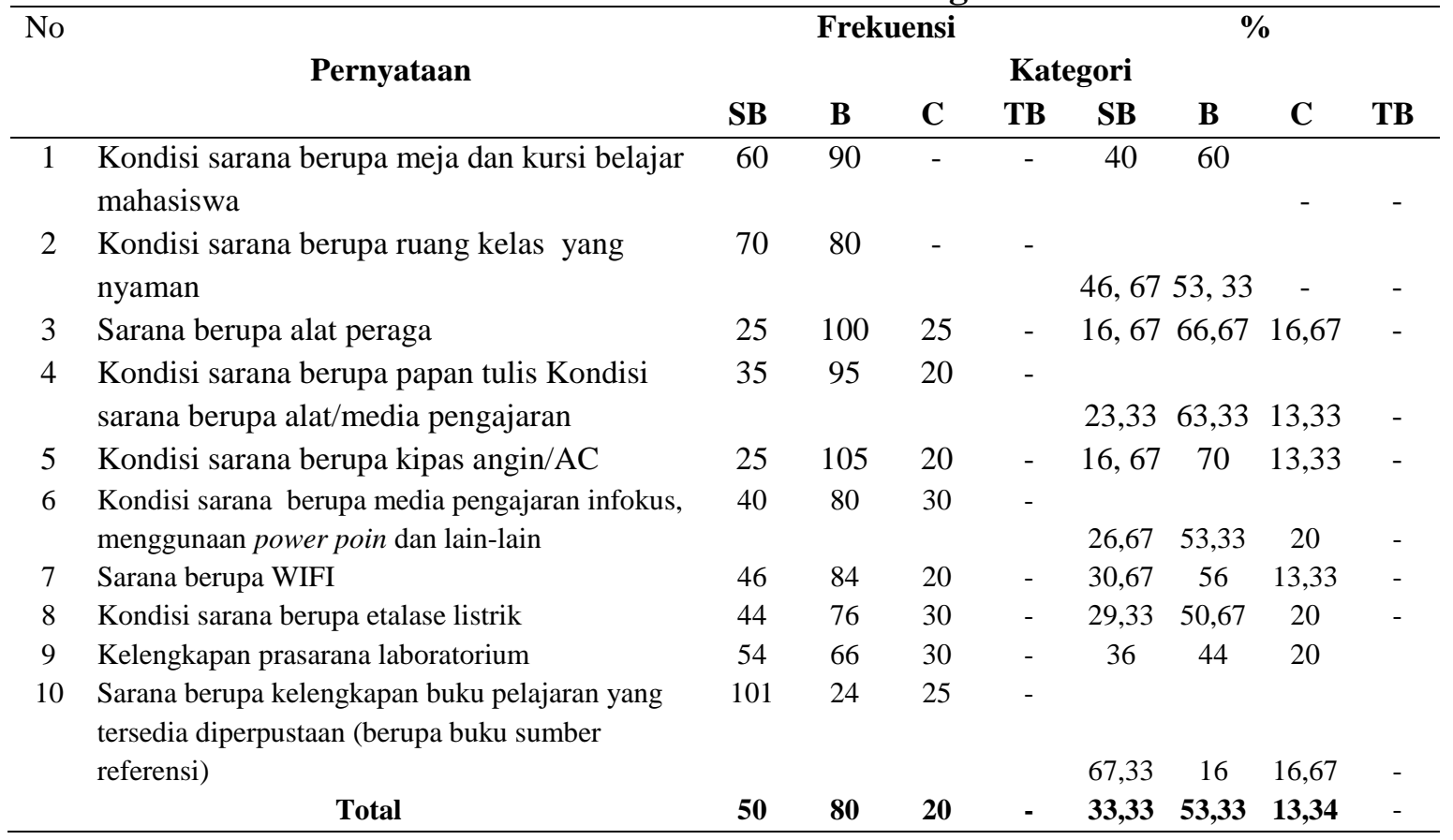

Angket dibagikan pada mahasiswa jurusan IPS yaitu: Pendidikan Akuntansi, Pendidikan Geografi dan Pendidikan Sejarah yang dijadikan sampel penelitian yaitu sebanyak 150 mahasiswa, sedangkan angket uji coba diberikan kepada mahasiswa program studi pendidikan akuntansi di luar sampel penelitian. Hasil analisa data yang telah terkumpul melalui angket FKIP Jurusan IPS di Universitas PGRI Palembang dapat dilihat pada tabel 5 di bawah ini : bahwa sarana di Universitas PGRI

Palembang dalam keadaan baik, hal ini dapat dilihat yang terbanyak pada kategori Baik yaitu $53,33 \%$.

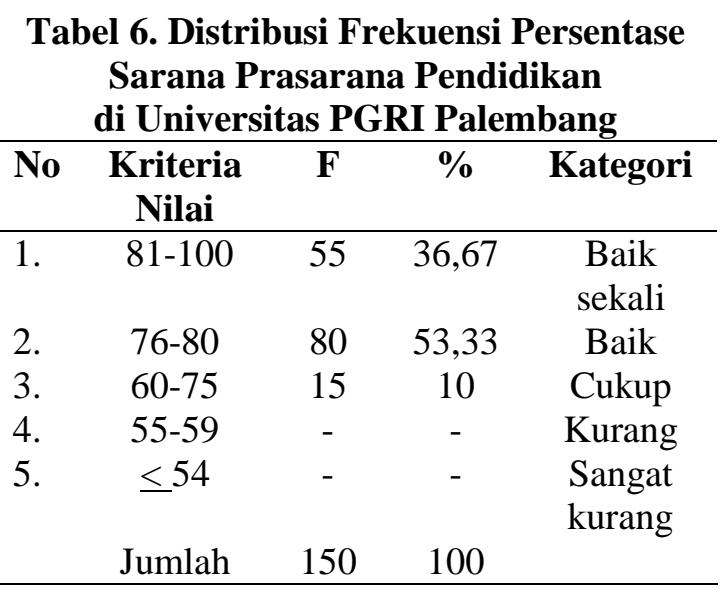

Dari data di atas, dapat disimpulkan bahwa sarana prasarana jurusan IPS di Universitas PGRI Palembang sudah Baik, hal ini dapat dilihat pada kategori Baik 
Sekali yaitu 36,67\%, Baik yaitu 53,33\% dan Cukup 10\%. Lebih jelasnya dapat dilihat pada diagram di bawah ini.

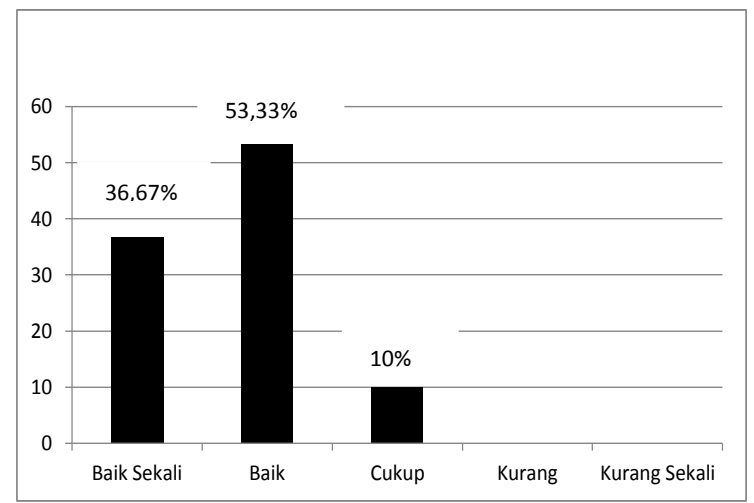

Gambar. Distribusi Frekuensi Persentase Sarana Prasarana Pendidikan di Universitas PGRI Palembang

Menurut Matin dan Fuad (2016 : 01) "sarana prasarana pendidikan merupakan salah satu sumber yang penting dalam menunjang proses pembelajaran di Sekolah". Dalam penelitian ini adalah Perguruan Tinggi, keberhasilan program pendidikan di Perguruan Tinggi sangat dipengaruhi oleh kondisi sarana prasarana pendidikan yang dimiliki Perguruan Tinggi dan optimalisasi pengelolaan dan pemanfaatannya. Hal ini menunjukkan bahwa sarana prasarana pendidikan dapat dianggap sebagai salah satu faktor yang turut mempengaruhi hasil belajar Mahasiswa.

Berdasarkan pernyataan mahasiswa Jurusan IPS yang diberikan Angket, yaitu sebanyak 150 Mahasiswa, dengan 30 Pernyataan. (1) Indikator Pernyataan Kondisi sarana berupa meja dan kursi belajar mahasiswa dengan persentase Sangat Baik
40\% dan Baik 60\%. (2) Indikator Kondisi sarana berupa ruang kelas yang nyaman dengan persentase Sangat Baik 46,67\% dan Baik 53,33\%. (3) Indikator Sarana berupa alat peraga dengan persentase Sangat Baik 16, 67\%, Baik 66,67\% dan Cukup Baik 16,67. (4) Indikator Kondisi sarana berupa papan tulis Kondisi sarana berupa alat/media pengajaran dengan persentase Sangat Baik 23,33\%, Baik 63,33\% dan Cukup Baik 13,33\%. (5) Indikator Kondisi sarana berupa kipas angin/AC dengan persentase Sangat Baik 16,67\%, Baik 70\% dan Cukup Baik 13,33\%. (6) Indikator Kondisi sarana berupa media pengajaran infokus, menggunaan power poin dan lain-lain dengan kategori Sangat Baik 26,67\%, Baik 53,33\% dan Cukup Baik 20\%. (7) Indikator Sarana berupa WIFI dengan persentase Sangat Baik 30,67\%, Baik 56\% dan Cukup Baik 13,33. (8) Indikator Kondisi sarana berupa etalase listrik dengan persentase Sangat Baik 29,33\%, Baik 50,67\% dan Cukup Baik 20\% (9) Indikator Kelengkapan prasarana laboratorium dengan persentase Sangat Baik 36\%, Baik 44\% dan Cukup Baik 20\%. (10) Indikator Sarana berupa kelengkapan buku pelajaran yang tersedia diperpustaan (berupa buku sumber referensi) dengan persentase Sangat Baik 67,33\%, Baik 16\% dan 16,67\%.

Berdasarkan pemaparan di atas dapat disimpulkan dari 10 indikator tersebut yaitu dengan persentase sebesar Sangat Baik 
33,33\%, Baik 53,33\%, Cukup Baik 13,34\% dan Tidak Baik tidak ada. Pada hasil analisis disribusi persentase tiap kategori penilaian, diketahui bahwa sarana prasarana pendidikan yang termasuk dalam kategori "Baik sekali" 81-100 sebesar 36,67\%, kategori "Baik” 7680 sebesar 53,33\%, kategori "Cukup" 70-75 sebesar 10\%, pada kategori "Kurang" 55-59 sebesar $0 \%$ dan pada Kategori "Sangat kurang" sebesar 0\%. Dapat disimpulkan persentase sarana prasarana pendidikan yang terbesar yaitu 53,33\% dengan kategori "Baik". Jadi dapat disimpulkan sarana prasarana di Universitas PGRI Palembang dalam Kategori Baik terlihat dari jumlah pernyataan mahasiswa yaitu sebesar $12.030 / 150=80,20$.

\section{KESIMPULAN DAN SARAN}

Berdasarkan hasil analisa data dan pembahasan yang telah diuraikan sebelumnya, maka dapat disimpulkan bahwa: sarana dan prasarana yang dimiliki oleh Universitas PGRI dalam Kategori Baik, berdasarka Pernyataan Mahasiswa Jurusan IPS, dengan rata-rata yaitu Sebesar 80,20 dengan persentase tertinggi $53,33 \%$ dalam kategori Baik.

Berdasarkan hasil penelitian maka penulis memberikan saran sebagai berikut:

1) Hendaknya pihak Perguruan Tinggi lebih Optimal lagi dalam memperhatikan sarana prasarana pendidikan di Universitas PGRI Palembang, melengkapi sarana prasarana pendidikan yang mendukung proses pembelajaran dan memberikan pelayanan yang terbaik kepada mahasiswa.

2) Mahasiswa hendaknya ikut berperan aktif dan ikut berperan serta dalam merawat dan menjaga segala fasilitas yang ada di Universitas PGRI Palembang, termasuk sarana dan prasarana.

3) Penelitian ini dapat menjadi referensi bagi peneliti selanjutnya yang berkaitan dengan sarana prasarana.

\section{UCAPAN TERIMA KASIH}

Peneliti mengucapkan terimakasih kepada

Universitas PGRI Palembang.

\section{DAFTAR PUSTAKA}

Aprilana, E. R., Kristiawan, M., \& Hafulyon, H. (2017). Kepemimpinan Kepala Madrasah Dalam Mewujudkan Pembelajaran Efektif di Madrasah Ibtidaiyah Rahmah El Yunusiyyah Diniyyah Puteri Padang Panjang. Elementary, 4(1).

Arikunto, Suharsimi. (2014). Prosedur Penelitian Suatu Pendekatan Praktik. Jakarta: PT Rineka Cipta.

Daryanto. (2008). Administrasi Pendidikan. Jakarta: PT Rineka Cipta

Kristiawan, M. Safitri, D. \& Lestari, R. (2017). Manajemen Pendidikan. Yogyakarta: Deepublish

Matin dan Nurhattati Fuad. (2016). Manajemen Sarana Prasarana Pendidikan. Jakarta: PT Raja Grafindo Persada. 
Peraturan Menteri Riset, Teknologi, Dan Pendidikan Tinggi Republik Indonesia Nomor 44 Tahun 2015 Tentang Standar Nasional Pendidikan Tinggi.

Purwanto. (2013). Evaluasi hasil belajar. Yogyakarta: Pustaka Pelajar.

Rohman, Muhamad dan Amri Sofan. (2012). Manajemen Pendidikan. Jakarta: PT Prestasi Persada.

Sudijono, Anas. (2010). Pengantar Evaluasi Pendidikan. Jakarta: PT RajaGrafindo Persada.

Sugiyono. (2014). Metode Penelitian Pendidikan Pendekatan Kuantitatif, Kualitatif, dan $R \& D$. Bandung: Alfabeta.

Undang-undang Republik Indonesia Nomor 12 Tahun 2012 Tentang Pendidikan Tinggi. 